\title{
Performance Evaluation of a Dehusking and Shelling Machine for Castor Fruits and Seeds
}

\author{
${ }^{1}$ Balami, A. A., ${ }^{1}$ Adgidzi, D., ${ }^{2}$ Kenneth, C. A., and ${ }^{3}$ Lamuwa, G. \\ ${ }^{I}$ Department of Agricultural and Bioresources Engineering, Federal University of Technology, P. M.B. 65, \\ Minna, Nigeria \\ ${ }^{2}$ Enugu State University of Science and Technology, Enugu, Nigeria \\ ${ }^{3}$ Dept of Agric. Engineering, Ramat Polytechnic, Maiduguri, Nigeria
}

\begin{abstract}
The performance evaluation of a locally developed castor fruits and seeds dehusking and shelling machine was carried out. The development of the machine was embarked upon in order to reduce the drudgery associated with the processing of castor oil. The machine consists of two major compartments, the shelling unit and the dehusking unit. A blower was incorporated to facilitate easy and proper cleaning and separation of the seeds from the chaffs. Performance tests were carried out using two different accessions of castor seeds (the large and small castor seeds at three different drum speeds of $240 \mathrm{rpm}, 320 \mathrm{rpm}$ and $400 \mathrm{rpm}$, using $1000 \mathrm{~g}$, $2000 \mathrm{~g}$ and $3000 \mathrm{~g}$ of both castor seeds, each one replicated three times. The results show that the shelling efficiency and seed recovery rate of the machine decreased as the speed of the drum increases (at $240 \mathrm{rpm}$ $80.34 \%$ and $99.50 \%$ ), respectively and at $400 \mathrm{rpm}-76.28 \%$ and 99.18), respectively, while the percentage losses in seeds, cleaning efficiency and mass flow rate of the material increased as the speed of the drum increases ( at $400 \mathrm{rpm}-0.98 \%, 51.23 \%$ and $23.18 \mathrm{~g} / \mathrm{s}$ and $240 \mathrm{rpm}-0.50 \%, 50.63 \%$ and $15.21 \mathrm{~g} / \mathrm{s}$ ), respectively. The results of the ANOVA indicate that the shelling efficiency of the machine differs significantly at the three drum speeds. The analysis also shows that the machine performed better at 240 rpm compared to the other two speeds. It can be concluded, that the developed machine could reduce the drudgery involved in manual shelling with saving in operating time of about $70 \%$.
\end{abstract}

Keywords: Castor, Dehusking, Shelling, Machine, drudgery

\section{INTRODUCTION}

Castor (Ricinus communis) belongs to the Euphorbiaceae or spurge family (Phillips and Martyn, 1999; http://www.billcasselman.com/cwod_archive/beaver_castor_two.htm), containing a vast number of plants native to the tropics. It is a semi-tropical perennial grown extensively in warm-temperature and tropical regions of the world. Castor plants can be basically divided into two types, tall (giant) and short (dwarf). The caster plant is a robust annual plant that grows between $2-5$ meters in one season with a temperature of about $23^{0} \mathrm{c}$ and relative humidity of about $50 \%$. Castor seed is a drought resistant crop, needing between $380-500 \mathrm{~mm}$ of rain during a growing season of between 140 - 150days. It does not tolerate heavy rainfall or water logging. It prefers deep sandy loam soil with a ${ }_{\mathrm{p}} \mathrm{H}$ of 6 (Weiss, 1983; Popova, 1963). Under dry conditions, yields are about 1.0 to 1.2 t/ha but reaches 1.5 to $1.8 \mathrm{t} / \mathrm{ha}$ under irrigation. Fertilizer requirements for castor are similar to those of sun flower (40 - $60 \mathrm{~kg}$ of Nitrogen and $50 \mathrm{~kg}$ of phosphorus and potassium per hectare). Good yield responses have been obtained from $75 \mathrm{~kg} / \mathrm{ha}$ of Nitrogen and $25 \mathrm{~kg} / \mathrm{ha}$ of both phosphate and potash. Unbalanced nitrogen application encourages growth of foliage at the expense of flower and seed formation. Castor grows both in the wild and cultivated. Castor seed originated in Africa and grows in the wild in East and North Africa. It has numerous uses. A poultice of castor leaves is useful as an external application to boils and swellings. Coated with some bland oil such as coconut oil and heated, the hot leaves can be applied over guinea-worm sores to extract the worms. A paste of kernel without the embryo, boiled in milk, is also given as a medicine for the treatment of lumbago, rheumatism and sciatica (Lewis and Elvin-Lewis, 1977; Simpson and Ogorzaly, 1986). Castor oil is regarded as one of the best laxative and purgative preparations available. It is of particular benefit for children and pregnant women due to its mild action in easing constipation, colic and diarrhea due to slow digestion. Castor oil is used for a range of industrial purposes from soap making to vanishes. Castor oil is used very effectively in the treatment of rheumatic and skin disorders. The oil of castor is massaged over the breast after child birth to increases the flow of milk, as it stimulates the mammary glands. Castor leaves can also be used to foment the breasts, for the same purpose. If used regularly as hair oil, it helps the growth of the hair and cures dandruff (Zahir et al., 2010). 
Other uses and benefits of castor seeds are; according to Ayurvedic and Unani Treatises (Lewis and Elvin-Lewis, 1977), as natural birth control, if a woman chews one castor seed daily for a period of seven days after menstruation, she becomes sterile. This has been interpreted by many that castor seed is an herb for birth control and if the woman swallows one castor seed, after the menstrual circle, she will not conceive during that month. When pregnancy is desired, the practice can be given up and conception follows after a year. Castor oil massaged over the body, before birth keeps the skin healthy and imparts sound sleep. Such an oil bath may be taken once a week. Applying castor oil over hand and feet before going to bed keeps them soft and similarly over the eyes brows and eye lashes keeps them well groomed (Marter, 1981; Gideon, 1965).

The negative aspects of castor oils are: repeated use of castor oils as a laxative causes secondary constipation that is recurrence of the condition after cure. Persons suffering from kidney infection should not take castor oil as a purgative. It should also not be used when there is abdominal pain or intestine infections such as appendicitis, enteritis or inflammation of the small intestine and peritonitis. Large doses of castor oil during the early months of pregnancy may cause abortion (Windholz et al., 1983).

According to FAO (2008), the world production of castor seed was 1, 209, 756 metric tones. India is the largest producer of castor seed followed by China, Brazil, Ethiopia and Paraguay accounting for about $85 \%$ of the global production of seed. The statistical data of castor production in Nigeria has not yet been found because farmers in Nigeria are not growing castor in large quantities.

Often before castor is used it has to be processed. One of the major problems in the post harvest processing of castor is the dehusking and shelling of the castor fruits and seeds. Basically castor can be processed by traditional and mechanical method. The traditional method makes use of little or no modern technology, (i.e. the seed is separated from the spiny husk by sun drying in the open until the casing splits, foreign materials are separated by hands picking, dehusking and shelling process is manual, after that the kernels are crushed into paste (Cake) form using mortar and pestle, then the oil extracted by boiling the crushed seed in water and allowing the oil to float to the surface where it is schemed off) hence poor quality of oil extraction (Nkpa et al., 1989). On the other hand, the mechanical methods (that is the use of machines) available are yet to meet the required efficiency and the quality of oil extracted. Consequently, dehusking and shelling of castor through the traditional method is tedious, time consuming and of low quality. In developed countries there basically two types of castor seed sheller which include power operated and hand operated shellers. The power operated is usually equipped with rubber - covered vertical discs. One disc is stationery, while the other is rotated by an electric motor, which also powers cleaning fan to separate the hulls from the seed. The distance between the discs is adjustable permitting efficient hulling without excessive cracking of the seed coat (Schoenleber and Taylor, 1954). The hand - powered sheller has the same configuration with the power operated sheller. In Nigeria, castor is processed locally through the traditional method which makes use of little or no modern technology. Here, the seed is separated from the spiny husk by prolonged sun drying in the open until the casing splits or are beaten or rubbed with wooden plank. In most parts of the country, the pods after harvest are collected into heaps over which water is sprinkled to soften the husk and facilitate dehusking. Prolonged exposure of castor to sun or heat does affect the oil content of the seed. The traditional method of processing castor is tedious, time consuming and low productivity and energy sapping.

The aim of this research work is design, construct and carry out the performance evaluation of a machine that is capable of dehusking and shelling castor fruits and seeds.

\section{MATERIALS AND METHODS}

2.1 Material selection: The materials used for constructing the dehusking and shelling machine were chosen on the basis of their availability, suitability, economy, viability in service among other considerations (Sharma and Aggarwal, 1998; Gupta and Das, 1997; Sahaya and Singh, 1994; Mohsenin, 1984). The machine consists of two major components: the shelling unit which breaks and separates the seed from the fruit and the dehusking unit which cracks and dislodges the inner shell from the nut. A blower was incorporated to facilitate easy and proper cleaning and separation of the seeds from the chaffs. The machine is operated by a $3 \mathrm{hp}$ electric motor. The isometric drawing of the machine is shown in fig.1. 


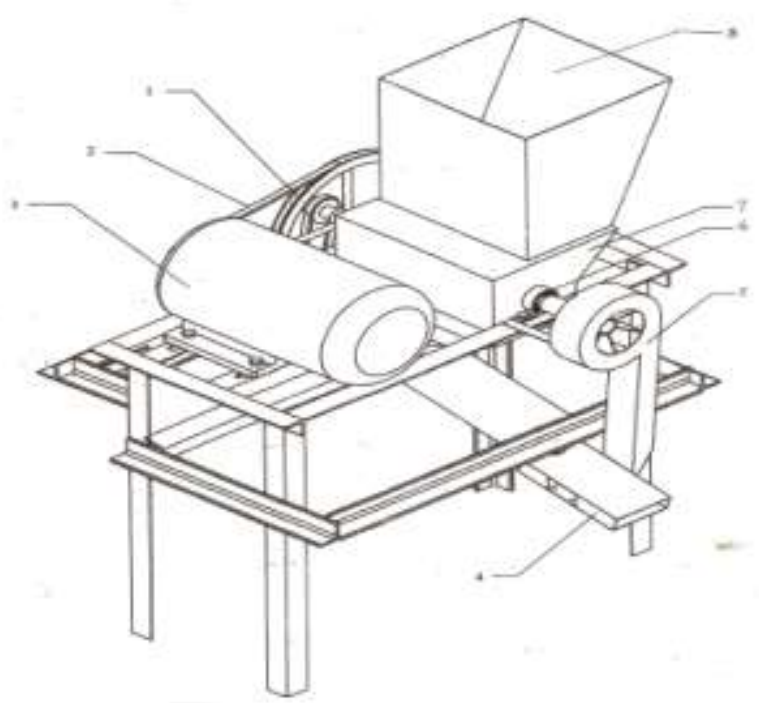

Fig. 1: Castor Dehusking and Shelling Machine

1 - Driving Pulley; 2 - Vee - Belt: 3 - Electric Motor: 4 - Discharge Chute: 5 - Blower Casing: 6 - Bearing Housing: 7 - Shelling Casing; 8 - Hopper

\subsection{Performance Evaluation of the Machine:}

The machine was first run under the no - load condition using an electric motor of $3 \mathrm{hp}$ with speed rating of $1440 \mathrm{rpm}$, whereas the metallic drum spikes shaft was run at a speed of $240 \mathrm{rpm}$ under the no-load condition. Essentially, the no-load test was carried out to ascertain the smoothness of operation for the machines rotating parts. The actual test was conducted using two different accessions of castor pods which include large and small seeds. Testing of the machine was targeted at evaluating its shelling efficiency, cleaning efficiency, and percentage losses and seed recovery rate. $3000 \mathrm{~g}$ each of large and small castor pods were obtained from the market and were divided into three equal measures of $1000 \mathrm{~g}$ each for both large and small castor pods. The performance test was conducted for each accession of castor pod using $1000 \mathrm{~g}$ and replicated three times. The test data generated were analyzed using the Analysis of variance technique (ANOVA).

\section{RESULTS AND DISCUSSION}

3.1 Results: The results obtained are given Tables 1, 2 and 3 while the ANOVA result is presented in Table 4 .

Table 1: Results obtained by using large castor seeds

\begin{tabular}{|c|c|c|c|c|c|}
\hline $\begin{array}{c}(\mathrm{A}) \\
\begin{array}{c}\text { Weight of } \\
\text { castor }\end{array}\end{array}$ & $\begin{array}{c}(\mathrm{B}) \\
\text { Weight of } \\
\text { castor seed }\end{array}$ & $\begin{array}{c}\text { Weight of castor } \\
\text { seeds not shelled }(\mathrm{g})\end{array}$ & $\begin{array}{c}\text { (D) } \\
\text { Weight of } \\
\text { chaff not }\end{array}$ & $\begin{array}{c}(\mathrm{E}) \\
\text { Weight of chaff } \\
\text { blown out }(\mathrm{g})\end{array}$ & $\begin{array}{c}(\mathrm{T}) \\
\text { Time of } \\
\text { shelling (s) }\end{array}$ \\
\hline 1000 & 725.40 & 120.20 & 82.00 & 69.30 & 65.00 \\
\hline 1000 & 737.60 & 119.40 & 78.20 & 61.40 & 67.00 \\
\hline 1000 & 725.70 & 121.30 & 74.30 & 73.70 & 66.00 \\
\hline Average & 729.57 & 120.30 & 78.17 & 68.13 & 66.00 \\
\hline
\end{tabular}

Table 2: Results obtained by using Small castor seeds

\begin{tabular}{|c|c|c|c|c|c|}
\hline $\begin{array}{c}(\mathrm{A}) \\
\text { Weight of } \\
\text { castor } \\
\text { seeds } \\
\text { introduced }\end{array}$ & $\begin{array}{l}\quad(B) \\
\text { Weight of } \\
\text { castor seed } \\
\text { shelled }(g)\end{array}$ & $\begin{array}{l}\text { (C) } \\
\text { Weight of castor } \\
\text { seeds not shelled }(\mathrm{g})\end{array}$ & $\begin{array}{l}\quad(\mathrm{D}) \\
\text { Weight of } \\
\text { chaff not } \\
\text { blown out }(\mathrm{g})\end{array}$ & $\begin{array}{l}\text { (E) } \\
\text { Weight of chaff } \\
\text { blown out }(g)\end{array}$ & $\begin{array}{l}\quad(\mathrm{T}) \\
\text { Time of } \\
\text { shelling (s) }\end{array}$ \\
\hline 1000 & 616.10 & 227.60 & 74.10 & 78.60 & 68.00 \\
\hline 1000 & 609.60 & 230.10 & 76.30 & 79.20 & 67.00 \\
\hline 1000 & 615.20 & 228.20 & 75.80 & 76.70 & 69.00 \\
\hline Average & 613.63 & 228.63 & 75.40 & 78.17 & 68.00 \\
\hline
\end{tabular}


Table 3: Summary of the Results

\begin{tabular}{|c|c|c|c|}
\hline Parameters & Large Castor Seeds & Small Castor Seeds & Average \\
\hline $\begin{array}{c}\text { Shelling Efficiency, } \\
\%(A)\end{array}$ & 85.50 & 72.86 & 79.33 \\
\hline $\begin{array}{c}\text { Percentage Losses, } \\
\% \text { (B) }\end{array}$ & 0.38 & 0.42 & 0.40 \\
\hline $\begin{array}{c}\text { Cleaning Efficiency, } \\
\% \text { (C) }\end{array}$ & 46.57 & 50.90 & 48.74 \\
\hline $\begin{array}{c}\text { Seed Recovery } \\
\text { Rate, \% (D) }\end{array}$ & 99.62 & 99.58 & 99.60 \\
\hline $\begin{array}{c}\text { Mass Flow Rate, } \\
\text { Kg/s (E) }\end{array}$ & 15.15 & 14.71 & 14.93 \\
\hline
\end{tabular}

Table 4: Result of ANOVA obtained for the Efficiency of the Developed Machine

\begin{tabular}{|l|c|c|c|c|}
\hline & Sum of the square & Degree of freedom & Mean Square & Computed $\mathrm{F}_{0}$ \\
\hline $\begin{array}{l}\text { Shelling } \\
\text { Efficiency, (A) }\end{array}$ & 1093.77 & 1 & 1093.77 & 0.5297 \\
\hline $\begin{array}{l}\text { Percentage } \\
\text { Losses, (B) }\end{array}$ & 2122.09 & 1 & 2122.09 & 1.0277 \\
\hline $\begin{array}{l}\text { Cleaning } \\
\text { Efficiency, (C) }\end{array}$ & - & 1 & -0.2056 & -0.0001 \\
\hline $\begin{array}{l}\text { Seed Recovery } \\
\text { Rate, (D) }\end{array}$ & 2802.60 & 1 & 2802.60 & 1.3572 \\
\hline $\begin{array}{l}\text { Mass Recovery } \\
\text { Rate, (E) }\end{array}$ & 2155.46 & 1 & 2155.46 & 1.0438 \\
\hline Error & 8259.95 & 4 & 2064.99 & - \\
\hline Total & 16433.66 & 9 & - & - \\
\hline
\end{tabular}

Significant at $5 \%$ probability level

\subsection{Discussion:}

The performance test carried out was to determine the efficiency of the machine using two accessions of castor seed. Table 1 gives the average weights of castor seed shelled, castor seed not shelled, chaff not blown out and chaff blown out for three samples of large castor seeds. The average weight of castor seed shelled, castor seed not shelled, chaff not blown out and chaff blown out recovered after dehusking and shelling large castor seeds are $729.57 \mathrm{~g}, 120.30 \mathrm{~g}, 78.17 \mathrm{~g}$ and $68.13 \mathrm{~g}$, respectively. This shows that the shelling efficiency and seed recovery rate was high and the average time used for the three sample was 66 seconds.

In Table 2, the average weights of castor seed shelled, castor seed not shelled, chaff not blown out and chaff blown out recovered after dehusking and shelling 3 samples of small castor seeds are given as $613.63 \mathrm{~g}, 228.63 \mathrm{~g}$, $75.40 \mathrm{~g}$ and $78.17 \mathrm{~g}$, respectively. The average time used for dehusking and shelling small castor seeds for the three samples was 68 seconds.

Table 3 gives the summary of the results for the dehusking and shelling of castor seed. The average shelling efficiency, percentage losses, cleaning efficiency, seed recovery rate and mass flow rate calculated are given as $79.33 \%, 0.40 \%, 48.74 \%, 99.60 \%$ and $15.15 \mathrm{Kg} / \mathrm{s}$, respectively.

The average time used for the constructed machine for dehusking and shelling $1000 \mathrm{~g}$ of castor seeds was 67 seconds and that of convectional method of manual dehusking and shelling was 198 seconds. Therefore, the constructed machine could reduce the drudgery involved in manual shelling with a saving in operating time of about $70 \%$ compared to conventional method of manual dehusking and shelling of castor seeds.

From the test carried out, the average cleaning efficiency, seed recovery rate and mass flow rate were calculated as $48.78 \%, 99.60 \%$ and $14.93 \mathrm{Kg} / \mathrm{s}$. The cleaning efficiency was low which should be improved on, while the seed recovery rate was high, showing that $99.60 \%$ materials was recovered and mass flow rate was normal which shows that the fabricated machine saves time involved in dehusking and shelling castor seeds manually by beating or rubbing the seeds with wooden plank.

The ANOVA for the analysis of result for dehusking and shelling castor seeds using the developed machine was given in Table 4 . The condition of adequacy is given as $F_{\text {cal }} \leq F_{\text {table. }} F_{\text {table }}=7.71$, which is greater than all the calculated F distribution $=0.5297$. Therefore, the condition is satisfied and the developed machine model is adequate. 


\section{CONCLUSIONS}

The performance evaluation of a locally developed castor fruit and seeds dehusking and shelling machine was successfully carried out. The machine was evaluated using two accessions of castor seeds and the following results obtained: average shelling efficiency $-79.33 \%$, percentage losses $-0.40 \%$, cleaning efficiency $-48.74 \%$, seed recovery rate $-99.6 \%$ and mass flow rate $-14.93 \mathrm{~kg} / \mathrm{s}$. The shelling efficiency of the machine differs significantly at different drum speeds. The developed machine could reduce the drudgery involved in manual shelling with saving in operating time of about $70 \%$.

\section{References}

[1] Food and Agricultural Organisation of the United Nations (2008): Economic and Social Department. The Statistical Division. http://en.wikipedia.org/wiki/Castor_oil_plant. Retrieved June, 2012.

[2] Gideon, C. A. (1965): Castor Cultivation in India, India Central Oil seeds Committee Hydrerabad, India.

[3] Gupta, R. K and Das, S.K (1997): Physical Properties of Sunflower seed. Journal of Agricultural Engineering Research. (p. 66, 85-91).

[4] http://www.billcasselman.com/cwod_archive/beaver_castor_two.htm. Retrieved 2012-06-14.

[5] Lewis, W. H and Elvin-Lewis, M. P. F (1977): Medical Botany: Plants Affecting man's Health. John Wiley and Sons New York.

[6] Marter, A. D. (1981): Castor - Markets utilization and prospects. Tropical Production Institute London.

[7] Mohsenin, N. N. (1984): Physical Properties of Food and Agricultural Materials. A Teaching Manual, Gordon and Breach Scientific Publishers New York.

[8] Nkpa, N. N Arowolo, T. A and Akpan, H. J (1989): Quality of Nigerian Palm oil after bleaching with local treated clay, JAOCS, Journal of the American Oil Chemists' Society.

[9] Phillips, R., Martyn, R., (1999). Annuals and Biennials. London: Macmillan. p. 106. ISBN 0-333-74889-1.

[10] Popova, E.V (1963): Castor Oil plant, Lenin Academy of Agriculture Scientific and Industrial Application. Botany Men, Culture Lenin, U.S.S.R.

[11] Sahaya, K. M and Singh, K. K (1994): Unit Operations of Agricultural Processing. Vikas publishing house PVT. Limited Jang Puna, New Delhi, India.

[12] Schoenleber, L.G and W. E Taylor (1954): Development of a portable Castor Bean huller Agric Engineering Journal p.35, 237326.

[13] Sharma, P. C and Aggarwal, D.K (1998): Machine Design (Mechanical Engineering Design) in S.I Units S. K Kataria and Sons publishers and Book Sellers, Delhi, India.

[14] Simpson, B. B. and M. C. Ogorzaly (1986): Economics Botany: Plants in our World. M. C Graw-Hill, New York.

[15] Weiss, E. A. (1983): Oil Seed Crops. Tropical Agricultural Science, Longman London.

[16] Windholz, M, S. Budavari, R. F, Blumetti and E. S OHerbein (1983): The Merck index; An Rahway Encyclopedia of Chemicals, Drugs, and Biological, Merck and Co inc., New Jersey.

[17] Zahir A.A., Rahuman A.A., Bagavan A., Santhoshkumar T., Mohamed R.R., Kamaraj C., Rajakumar G., Elango G., Jayaseelan C., Marimuthu S. (2010): Evaluation of botanical extracts against Haemaphysalis bispinosa Neumann and Hippobosca maculata Leach" Parasitology Research 2010 107:3 (585-592). 